\title{
Analysis of the Present Condition of Garment Workers' Rights and Its Protection under Domestic and International Legal Framework: Bangladesh Perspective
}

\author{
Md. Al-Amin ${ }^{1}$, Shahidul Alam ${ }^{1}$ and Sohrab Hossain ${ }^{1}$ \\ ${ }^{1}$ Department of Law, Faculty of Arts \& Social Sciences, Gono Bishwabidyalay, Savar-1344, Dhaka, Bangladesh. \\ *Correspondence: mortayesh95@gmail.com (Md. Al-Amin, Lecturer, Department of Law, Gono Bishwabidyalay, Savar- \\ 1344, Dhaka, Bangladesh).
}

\begin{abstract}
Total economy of Bangladesh greatly depends on industrial sectors and the ready-made garment is a vital part of this sector. More than 4 million people are working in this sector and about 5000 garment factories are scattered across the country. Among them about 70 percent workers are women and they work equally with men from early morning to evening, which often extends to several hours at night, where their paid wages which they actually got are not in a satisfactory level. But we have to admit that, Proper management of labour is an essential matter for the growth of industrial sector and for that role of labour and industrial laws are of paramount importance. The main object to which the Labour law indicates is obviously to maintain peace in industrial sector and to meet the vibrancies of problems in workplace, not only that but also to protect and secure the essential rights of the workmen. But it is a matter to regret that various defects, loopholes and unwanted rules of labour laws are depriving the workers of their legal or basic rights and also indiscriminately been victimized. The main aims of this research are to clarify the rights and other conceptual issues regarding rights of the workers especially who work in the garments sector of Bangladesh in accordance with standard practice, domestic and international legal framework along with the pledge to search the main and top most loopholes of existing labour laws of our country. In this research, we have tried both qualitative and quantitative approach to make it more effective and fruitful. At the end of this research, we will try to discuss some international documents to assure the maximization of rights of the working class as well as to lessen the violation of their fundamental, legal or basic rights in the ready-made garments sector of our country.
\end{abstract}

Keywords: Workers, Rights, Protection, Violation, Safety, Remedies, Industries and Ready-made Garments.

\section{INTRODUCTION:}

Ready-made garment is one of the most leading industries in export business and central pillar of our country's economy. It earns around $\$ 34$ billion annually which is about 79 percent rise from 2013 when it was around $\$ 19$ billion and it makes our country the second largest exporter of garments in the world, with

UniversePG I www.universepg.com the sector accounting for 80 percent of total export earning of Bangladesh (Sultana, 2020) ${ }^{1}$. It is good to hear that about 5000 garment factories are now continuing their business and supporting 10 million livelihoods depending on it directly or indirectly. And the good news is that among them about 60-74 percent of workers are women ${ }^{2}$. So as Bangladesh is a leading garment wear exporting nation in the world, it is 
important for everybody's interest to sustain this industry which has changed the lives of many people's specially women. This sector has given employment to so many rural poor and women of our country, but their rights as workers fall considerably below international standards ${ }^{3}$. Moreover, Hazardous working condition and negligence of carrying are resulting death of many workers through factory fires and sudden collapses.

Above this aspect, in this Article we have discussed various problems of the workers, their life style, the notion of rights together with the rights obtained or deprived from enjoying by the workers who works in garments sector, various reasons for violation of rights of the workers of garments similarly the protection of those rights under different domestic and international Laws.

\section{Present Scenario of Workers' Right Violation in RMG Industries}

\subsection{Fire and building safety in Bangladesh's RMG} Industry: When the Tazreen Fashions factory burned down On November 24, 2012, it was the worst garment factory accident in Bangladesh's history where 112 workers lost their lives ${ }^{4}$. After five months of that incident in April 2013, when Rana Plaza collapsed, it was the most bitter garment factory accident in world history because at least 1,138 people were killed, and more than 2,000 were injured ${ }^{5}$. These tragedies spurred Bangladesh's government, global brands, the United States, other foreign governments, and international organizations into action. And several safety initiatives were taken to assure that none of the approximate 5000 operating apparel garments in Bangladesh will ever become another Tazreen or Rana Plaza. Two international initiatives the Europeanbased Accord on Fire and Building Safety in Bangladesh and the American-based Alliance for Bangladesh Worker Safety were created to improve factory building safety, and they have largely succeeded because of unprecedented work and collaboration among international labor advocates, industry leaders, brands, and the government of the Peoples Republic of Bangladesh. The U.S. government and the European Union applied diplomatic and economic pressure towards improvements for safety in factory and to a lesser extent, labor rights ${ }^{6}$. However, as both initiatives conclude their operations, the government of Bangladesh must now assume full responsibility for ensuring factory safety and protection of labour rights $^{7}$. But after considering national and international initiatives US Senate, committee on foreign relations put forward three vital questions and they think if positive movement can't be made on these key questions, Bangladesh RMG sector will face an uncertain future in a competitive fast-fashion market. These questions are as follows-

1) Will the government maintain the progress made in building safety and take additional measures to protect labour rights?

2) Will the new Ready-Made Garment Sustainability Council build upon the progress of the international initiatives continue to enhance safety in factories, promoting respect for labors and their rights, and protecting workers from abuse in workplace?

3) Will international brands insist on both building safety and respect for labour rights, including protection against workers' abuse? ${ }^{8}$

2.2 Violation of RMG workers' rights: We believe it is everybody's interest to sustain RMG industry an industry which has altered many people's life, especially women, in Bangladesh. But for long run custom, practiced over the years, hazardous conditions in workplace have resulted in deaths of many workers through tragic fires in factories and sudden collapses. Workers, in most of the cases young women, faces acutely difficult environment in workplace such as paid wages are below standard, long working hours, existence of forced labour and child labour, random sexual harassment by colleagues, high officials and employers, moreover freedom has curtailed in various mode, and there are a multitude of other trends which are against international standards and labour code of conducts. We have tried to find out several important violations of worker's rights which are as follows -

2.2.1 Forced overtime and unpaid wages - Workers are forced to put in far more hours per day than is allowed under the law for fulfilling production quotas which means compulsory overtime. Even workers are being forced to fulfill everyday's targets which are 
actually ordained unrealistically high. In most of the cases these workers worked almost seven days in a week to fulfill those targets and in return earn enough for their livings. Right to wages and equal remuneration for equally valued work without distinction of any kind has been guaranteed to the workers under Article 23 of UDHR. Beside this Article 15(2) of our constitution ensures the right to work at a reasonable wage having regard to the quantity and quality of work. Wages and benefits are one of the primary interests an employee may have, and unfortunately, disputes over the payment of wages and benefits are not uncommon (Rafique Rahman, 2012). The arduous hours and unpaid overtime are more shocking by the frequency with which workers are cheated out of payment for hours worked.

2.2.2 Grueling hours and unpaid leave - Though Bangladesh labour Act states in section 100 and 102 that, no adult worker shall ordinarily work or be required to work in an establishment for more than 8 (eight) hours in a day which may extend up to 10 (ten) hours subjected to extra-allowances and 48 (fortyeight) hours in a week which may extend up to 60 (sixty) hours in a week or in average 56 (fifty-six) hours per week in a year subjected to extra-allowances under section-108. But excessive working hours are still practiced as natural rule with a very nominal extra-allowances rather than exception. Law also stipulates that workers must receive 10 days of casual leave, 14 days sick leave in a year and 1 day Annual leave for every 18 working days where working in a shop or commercial or industrial establishment or factory but have to complete one year service continuously, plus a further 11 days leave for the festival, as of paid holiday for a calendar year ${ }^{9}$. But the scenario is not going according to law, almost in every factory workers need to work for 12 hours in a day mainly because of poor supply chain and infrastructure, insufficient utility service and high rate of migration ${ }^{10}$. International Labour Organization (ILO) has shown in a report in January, 2020 that 56 percent workers didn't take sick leave, 34 percent didn't take casual leave and 20 percent workers didn't get 11 (eleven) days entitled festival holidays ${ }^{11}$.

\subsubsection{Gender discrimination and Unsafe conditions}

- Workers, whether male or female, are equally treated UniversePG I www.universepg.com in the eye of law. Law doesn't permit any types of discrimination on the ground of sex; even there is no different identity like male or female workers. All of them are simply known as workers (ILO Convention on Equality of treatment (social security), 1962). This principle has also been recognized by ICCPR where the responsibility has been given to the state parties to ensure the recognized rights to all individuals within its territory and jurisdiction irrespective of their kind, race, sex, color, language, religion and so on (International Covenant on Civil and Political Rights, 1966). Moreover, binding rule of labour law is that employers must have to assure the basic standards for health, security and safety in the workplace. Article 23(1) of UDHR ensures the right to just and favorable condition for work which also indicates the safety measures in workplace for the workers. Despite this law, health, security and safety violations are rife in Bangladesh's garment factories. There is lacking of safe drinking water, even though many factories are poorly ventilated and often reach blistering temperatures. Similarly, in most of the factories where the people worked, did not have a functioning fire escape. Furthermore, access to toilet facilities is very low in most of the RMG factories. According to the Executive Director of the Accord, Rob Wayss, "it is common for the initiative to receive credible safety and health complaints of workers being slapped, pushed, and subjected to vulgar language, ${ }^{, 12}$.

\subsubsection{Job insecurity of garment workers - Job} security in RMG industry is a myth in this country. Workers are being suspended, dismissed, transferred or getting demotion and even sacked from the company at any time without any reasons. Though there has a clause in labour law that, terminated or discharged employee's due wages will have be paid within 30 (thirtieth) working day from the date of his termination $^{13}$, but in fact the due salary is not given sometimes. Very few companies abide by the rules of Govt. or BGMEA. Each company has its own rules as the company like to have it.

2.2.5 Lack of right to compensation - Workers sometimes have to do the risky task in the factory which creates tragic accident. And for that accident to families only earning member, other dependents of 
that family had to lead a miserable life. Though they have the right to get compensation but in almost every case they were being cheated. As an example, tragic death of garment workers caused by the recent Rana plaza devastation has grabbed many important lives and Govt. became successful to collect about 127 Corer Tk. to give to the victim as compensation. But it is a matter of great regret that the Govt. Could managed to allocate only 19 corers Tk. due to mismanagement caused by the corruption of the Govt. officials ${ }^{14}$. It is only an example; most of the time workers don't get proper compensation due to political influence and so on.

\subsubsection{Unfair labour practice and Workers Union -}

One of the main reasons behind the violation of workers' rights in ready-made garment industries is the active presence of unfair labour practice on employers' part. We can mention forceful discharge or dismissal as most used terms of unfair labour practice in RMG industries. By this unfair act employers hold the workers back from forming their Union or CBA. But almost every worker thinks that they need a Union to help for ending routine workplace abuses as well as to address boarder safety concern ${ }^{15}$. Though the tradition has changed and some efforts has been taken by our government after the incident of Rana Plaza disaster but still the number of factories in which the workers have their unions are very few and according to Human Rights Watch report the percentage of these factories are only 10 percent among all. What are the reasons behind these poor percentages? A union leader expresses his feeling to Human Rights Watch that "However raises their head suffers the most. Even union organizers were being physically assaulted by both manager and thugs (mastans) who acts in favour of the owners", 16 .

\subsection{Recent glaring examples of workers' rights} violation: If we try to look into the matter that what are the present scenario of RMG workers' rights violation in Bangladesh's RMG sectors then we will find that this scenario has been developed in last 7 years after the collapse of Rana Plaza in April, 2013 but it is still not in expected level. Most common topics for workers' rights violation are demand for standard wages, forced labour by the name of overtime, delay in paying monthly wages or festival UniversePG I www.universepg.com bonus, sudden dismissal or discharge, denial to approve paid maternity leave and verbal or physical harassment which we may also mention as sexual harassment in the workplace (Abdul Halim, 2011). The way through which RMG workers' express their labour unrest are mainly temporary strike, demonstration or protest rally, stay-in-strike, human chain, road or factory blockade and in more critical situation they go for violence or vandalism. In January, 2019 RMG workers from various factories of Savar and Ashulia, Dhaka started their movement demanding minimum wage and improvement of wage grade. Very soon that movement spread out in several other town in Dhaka city like Mirpur, Gulshan, Badda, Uttara and others. On $9^{\text {th }}$ January, 2019 workers from some factories of Savar comes out on the street and they block Dhaka-Aricha main road and about 11 A.M a clash takes place between RMG workers and law enforcing agencies (Police) where a worker named Sumon mia was died, his colleagues claim that sumon died by the gunshot of police ${ }^{17}$. After protesting continuously 10 days a tripartite meeting held among workers federation, owners association and the government. As a result of that meeting workers wages were adjusted. But comparing with pay scale gazette-2018 increased amount for $1^{\text {st }}$ grade is $747 \mathrm{tk}, 2^{\text {nd }}$ grade-786 tk, $3^{\text {rd }}$ grade- $255 \mathrm{tk}, 4^{\text {th }}$ grade- $102 \mathrm{tk}, 5^{\text {th }}$ grade- $20 \mathrm{tk}$, $6^{\text {th }}$ grade-15 and no change in $7^{\text {th }}$ grade $^{18}$. About that adjustment general secretary of Garment Workers Trade Union (GWTU) Joly Talukdar said to Deutsche Welle (dw.com) that "After this long run protest and sacrifice of a worker's life what the government did by the name of wage adjustment is nothing but a cheating" $" 19$. Alongside this, sudden dismissal or discharge ratio has increased alarmingly after this Covid19 pandemic situation. Though BGMEA got 10 thousands crore tk from the govt. to meet this pandemic challenges but workers laid off are still running and they didn't have full wages or bonus according to pay scale ${ }^{20}$. Moreover, every worker is entitled to get emergency sick leave but in almost every cases production in charge, line in charge or floor manager refuses to grant that leave. Such refusal incidents are very common in RMG sector for which many workers have already lost their valuable lives. As an example, Abdur Rob Mia (26) died in Cortz Apparel Ltd, Gazipur on 11 july, 2019. During his 
working time around 10:30 AM, he felt pain in his chest. His colleagues took him to the concerned doctor of that factory and doctor prescribes to take him to the hospital for better treatment. But when he applied for sick leave, production manager Shafiul Alam Aman misbehaved with him and refuses to grant sick leave. Then he came back to his working place and within 30 minutes he fell on the floor and became senseless. Quickly, his colleagues took him to the nearest $\mathrm{Al}$ Hera Hospital but doctor declared him as dead ${ }^{21}$.

Another remarkable death took place on 24 October, 2020 where a sewing operator of Zim \& Zesi composite Ltd, Gazipur named Mofidul Islam (32) joined in his regular factory work at $8 \mathrm{AM}$ but after sometime he felt pain in his chest, then he went to his line manager and seeks for leave but manager refused him and told him to take advise from the medical team. But when his condition started to deteriorate, authority permits him to go outside and then he got admitted to the nearest Tazuddin Ahamed Medical College Hospital where he died at $12 \mathrm{PM}^{22}$. Both of these cases factory authority unlawfully restrained them thats why they didn't got proper treatment on right time. Violation of such types of workers' rights exits in every factory of Bangladesh which remains untold or unknown in almost every cases.

\section{Protection of Garment Workers Right Under Domestic and International Laws}

Workers are considered as the wheel of this world. This modern world has built by the sweat, assiduity and hard work of this working class. Day after day they have undergone much more contrary situations but in no way they have given up their duties. In early period of the civilization, workers were the most suffered class. They had no rights, no privileges, no honor and even no social recognition or status. But workers have come through that darken period without being detached moreover they have gained strength and unity day by day. That unity have given them collective voice that's why they have earned social recognition, status, and honor and specified rights as a certain class. Today there are so many laws in national and international level to protect and preserve the rights of this working class. In this chapter we will try to discuss some important provisions from both

UniversePG I www.universepg.com domestic and international laws by which the recognition and rights of the workers has been ensured.

\subsection{Protection of workers' rights under the Bangla-} desh Labour Act: We have inherited most of the laws relating to the labour affairs from British-India and Pakistani period. There were about 50 (fifty) scattered or separated Laws on same subject matter, of which 15 (fifteen) were enacted by the Englishmen during the colonial period of British regime, 23 were passed during Pakistani period where only 12 were made after the independence of our country, regulating the powers and functions of the employer and establishing the rights and interest of the workers ${ }^{23}$. After the independence in 1971, as most of those previous Laws were outdated, scattered, inconsistent and often overlapping each other, in 1992 Govt. formed a Labour Law Commission which after examining 44 Labour Laws prepare a draft Labour Act in $1994^{24}$. This draft of Labour Act-1994 underwent series of changes in its vetting stages and finally The Bangladesh Labour Act was passed by the parliament on $11^{\text {th }}$ October 2006 and last amendment made in January, 2019. However, Main objectives for enacting Labour Act have been stated in its preamble. Those objectives are consolidating the laws relating to employment of workers, relations between workers and employers, determination of minimum rates of wages, payment of wages, compensation for injuries to workers during working hours, formation of trade unions, raising and settlement of industrial dispute, health, safety, welfare and working conditions and environment of workers and apprenticeship and matters ancillary thereto (Nirmal Chandra, 2007). However, here we will try to discuss some important rights protecting provisions from the Bangladesh Labour Act, 2006.

3.1.1 Right to wages and payment - Right to get proper wages and its payment is the topmost and foremost right of the workers. Wages means all remunerations expressed in terms of taka or capable of being so expressed, which, would if the terms of employment, expressed or implied, were fulfilled, be payable to a worker for his employment or of work done in such employment, and includes any other additional remuneration of the aforesaid nature ${ }^{25}$. Alongside these, according to section 120 of the said 
Act, bonus, remuneration payable for leave, holiday or extra hours work which means overtime, remuneration payable under the order of any court as award or settlement among the parties, any reword or sum payable for terminating from employment as well as sum payable due to lay-off or suspension will also be considered as wages for the employees. But the question is who will be responsible or liable for paying that wages? Yes, without any doubt employer is that person who will bear such responsibility. Section-121 states in this regard that, every employer shall be responsible for the payment to every worker employed by him and the other workers, who have been employed by the contractor or by the manager of any establishment, shall be paid by such contractor or manager. And if such contractor or manager didn't paid the wages then the employer of the establishment will pay to the workers. Workers will be entitled for payment in respect of their wage period which will not exceed a period of 1 (one) month ${ }^{26}$. The wages payable to any worker for a wage-period shall have to be paid within 7 (seven) working days which will count from the expiry date of that wage-period and all payment of wages shall have to be paid in day time of a working day. At the same time, in case of termination of employment whether by retrenchment, discharge, removal by the employer or termination by the worker, all wages payable to him shall have to be paid before the expiry of thirtieth working day following the day of termination of his employment ${ }^{27}$. Another condition is that all wages shall have to be paid in current coin, currency note or bank cheque ${ }^{28}$.

\subsubsection{Right to fixed working hours and leave - Fixed} working hours and leave are very essential for proper functioning of the employees. The Bangladesh Labour Act, 2006 have ensured these rights to workers. Any adult worker in any establishment shall not work ordinarily more than eight hours daily or not be required to work beyond this time ${ }^{29}$. But this time limit may extend up to ten hours as overtime as per section-108 of the Labour Act and extra allowance would be given for such overtime. But section-101 clearly states that, any worker shall not continue his/her work or duties after six hours in a particular day, unless he is given an interval of 1 (one) hour to take rest and meal and he will not continue his/her

UniversePG I www.universepg.com work or duties after passing five hours in a day, unless he is allowed half an hour interval on that day for same purpose. Hours of weekly working of an employee ordinarily will not exceed 48 (forty eight) hours in a particular week. But as per the condition of section-108, which is dealing with overtime, total hours of work of an employee in a particular week will not be exceed 60 (sixty) hours, and in case of a year that cannot be more than 56 (fifty six) hours on an average. Section-109 stipulates about female employees that "No female workers shall be allowed to work in any establishment from 10.00 O'clock at night to 06 O'clock in the morning without her permission',

Any worker engaged in any commercial or industrial unites shall have the right to enjoy holiday for 1 (one) day and 1.5 (One and half) days respectively for a shop and a factory in a particular week. Alongside this, they will also be entitled to one day of twenty four consecutive hours' holiday in a week if he/she works in a road transport establishment and for both of those leaves no deduction shall be made from his wages $^{30}$. Casual leave has also been ensured by section-115 of BLA, 2006 where it has been clearly mentioned that, every employee has the right to enjoy casual leave with full wages for 10 (ten) days in a calendar year. And section-116 allows 14 (fourteen) days of sick leave with full wages for every employee, except the newspaper workers, in a year. Workers will also entitle to get annual leave with full wages as per the condition of section-117 of BLA, 2006.

\subsubsection{Protection of Childs from employment and Adolescents from hazardous employment - Gener-} ally, child or adolescent couldn't be employed or even allowed to engage in work of any trade or in any other factories or establishment. But in special cases an adolescent can employed if he holds an ability certificate, given by a registered physician and carries that certificate while he is at work place. But this rule will not be applicable where such adolescent has employed as apprentice or for the vocational training in any occupation or establishment ${ }^{31}$. Further it has clearly been mentioned in section-35 of BLA, 2006 that no parent or legal guardian of any child can create any contract with any person giving permission in any way to employ the child in any work. Nevertheless, fitness certificate of an adolescent, given by registered 
physician shall be considered as valid for twelve months consecutively from the issuing date and employer shall be liable to pay the fee for the certificates $^{32}$. Furthermore, an adolescent couldn't be employed to any work declared as hazardous by the govt. or to clean lubricate or adjust any part of such machinery which is in motion ${ }^{33}$. About the hours of work for an adolescent, it is a certain rule of labour law that, if the working place is a factory or mine then the hours of work will not exceed five hours in per working day which will be 30 (thirty) hours in weekly basis and for other establishment it will not exceed seven hours per day which will be 42 (forty two) hours in weekly basis. But this rule is slightly different about overtime. The total hours of work including overtime will not exceed 36 (thirty six) hours for any factory or mine which will be 48 (forty eight) hours for other establishment in weekly basis, and employers can't keep working any adolescent between 7 o'clock in the evening to 7 o'clock in the morning ${ }^{34}$.

3.1.4 Right to get Compensation - Compensation is also an important right given to the workers for ensuring them that if any event harmful for health or accident happen during the work time in work place, they need not to feel them alone and law is always in their side. Section 150 stipulates that 'If any worker become bodily injured or get hurt by an accident during his work time as a part of his employment, then the employer will be liable for paying the compensation'. But in certain cases employer can get relief from this obligation, such as, if that workers doesn't lose his ability to work for not more than 3 consecutive days arising out of that injury or if at that time of accident such worker was drunken or use drugs before started his work and carries the influence of such drugs or if he willfully disobey the clear order of authority and safety rules. Not only that, if any worker files any suit for damages in any civil court then he will not get compensation. But prior to file damage suit in civil court if he submits any application claiming compensation in any labour court and if any agreement exists between him and his employer for providing compensation respecting those injury then no suit for damages will run (Bangladesh Labour Act, 2006). So, workers have the right to get compensation but this right is subjected to several other conditions.

UniversePG I www.universepg.com
3.1.5 Right to get maternity benefit - No employer, knowingly or unknowingly, shall employ any woman in his establishment or factory within eight weeks immediately after the day of her delivery of child or even that woman will also not engaged him to work in any forms of establishment within that period of eight weeks. If a woman informs her employer about the probability of being delivered then employer shall not employ such woman for doing such types of work where she needs to keep standing for a long time ${ }^{35}$. Every woman, who already has served for a minimum period of six months, shall have the right to get maternity benefit for preceding eight weeks and succeeding eight weeks from the date of delivery and the authority specifically the employer will be bound to pay her such benefit ${ }^{36}$.

3.1.5.1 Amount of maternity benefit; The amount of maternity benefit have to be paid at daily, weekly or monthly average rate of wages, fully in cash and for the determination of the daily, weekly or monthly average rate of wages, the total earned wages by that concerned woman in immediately preceding three months from the date of submitting her notice shall have to be divided by the total days of her works for which she actually worked during such period ${ }^{37}$.

3.1.5.2 Maternity benefit even in case of death; If a woman who is entitled to get maternity benefit dies on the day of delivery or within the period of eight weeks thereafter, the employer or employing authority shall pay the sum of benefit due, subjected to the survival of that child, to that person who takes the responsibility of that newly born child. Nevertheless, if a woman dies before giving birth of a child but if it happened within the allowed period for maternity benefit then the employer or employing authority shall have to pay such benefit ${ }^{38}$. Finally, it can be said at the end that, in almost every RMG industries, employees are depriving from their rights which is purely violation to the accord of compliance, the BLA, 2006 and the ILO based inter-national standard. The condition of works and rights which our apparel workers got are obviously the world's worst. All stakeholders involving employers, workers, governments and international as well as national bodies should come forward with the sense of togetherness to bring significant change in this industry. 
3.2 Protection of RMG workers' rights under the Constitution of Bangladesh: The peoples who work in the RMG sectors fall within the definition of the employee or worker. And as the citizen of this country these working people are also entitled to enjoy, same as others, the rights and protection delivered by the constitution. If we carefully look through our constitution there are some articles which have given some rights and protection to the workers. Those articles have discussed below -

It is the State's responsibility to emancipate the backward sections and this responsibility is fundamental in nature. According to Article 14, states fundamental responsibility is to release those people who fall within the class of toiling masses such as peasants and workers from all forms of exploitation. Similarly, the state shall endeavor to assure equal opportunity for all citizens and shall apply useful measures to set aside social inequality together with economic inequality from the society and its citizen. Alongside this, equitable distribution of wealth among citizens will also have to ensure ${ }^{39}$. Another basic obligation of the state is to secure the citizens right to work which means the right to guaranteed employment at a reasonable wage ${ }^{40}$. Nevertheless, it has clearly been mentioned that work is a right, a duty and a matter of honor for those citizens who are capable of working and those people will get proper remuneration for his labour according to the principle "from each according to his abilities, to each according to his work", 41 . Though these rights and principles can't enforceable by the court, but no one, intentionally or unintentionally can violate these rights. On the other hand, in the eye of law, all citizens are equal and are entitled to equal protection of law ${ }^{42}$. That means there is no discrimination between men and women or rich and poor and all are equally treated and protected by law. This view has also been supported by Art-29, view of this article is that, equal opportunity to be ensured for all the citizens which main aims is to create open field for employment or equal treatment for the service of the republic and respectively there should be no discrimination on any ground, such as religion, race, caste, sex or place of birth. Workers have also the right to personal liberty. Article- 32 of our constitution has guaranteed it. Alongside this, forced labour is prohibited in all its forms, guaranteed by our constitution and any forms of contravention to this principle shall be considered as offence which is punishable by $\mathrm{law}^{43}$. Forming trade union is also a guaranteed right by Article- 38 of the constitution, where freedom to form an association has been guarantee, so as of citizen, workers or employees of any establishment can enjoy this right to form trade union as an association. Not only that, profession or occupational freedom has also been saved by our constitution. Each citizen who is possessing required qualification, can engage himself in any legal profession and occupation. And can conduct any types of legal trade or business ${ }^{44}$.

Finally, it should not be wrong to say that, though we have constitutional safeguard about the basic rights of the labours but neither these are enough to fulfill the expectation nor manikin. Nevertheless, it has a great value indeed. Moreover, the rights enshrined in the fundamental rights chapter of our constitution can be enforced by the HCD, so we can't overlook or underestimate these rights.

\subsection{Protection of workers' rights under The} Factories Act, 1965: Factories Act, 1965 has adopted in Bangladesh with some basic objectives which are appointing the workers, determining standard minimum wages, safety in working places or factories, look after the hygiene and health issues, alongside with welfare, standard working hours, holidays and paid leave, along with the punishments and penalties for both the employees and owners for non-compliance of the requirements and laws. East Pakistan Factories Act, 1965 was first published on Dhaka Gazette, in September, 1965, and Bangladesh has adopted it after the independence. Followings are the basic rules regarding the protection of the worker's rights -

1. Govt. will appoint the chief inspector or other inspectors and also certifying surgeons for carrying out the purposes of this Act, as respect the inspection and certifying the fitness of different age's workers. And those certifying surgeons, as registered medical practitioner will responsible for the duties prescribed regarding the examination and 
certification of health and condition of the workers ${ }^{45}$.

2. This Act clearly stipulates that an worker who is adult shall not continue his/her work for a period exceeding forty-eight hours in a week or on holidays which may weekly or otherwise unless stated differently. Not only that workers will also have the right to get certain paid leaves such as annual leave, festival leave, casual leave and sick leave.

3. Any child under 14 years of age is forbidden to employ in any industry but an adolescent may be employed who have a fitness certificate issued by an authorized surgeon and for him working hours will be five hours in a day.

4. Every factory must have to ensure enough safety measures for fire incident and proper escaping way or emergency exit way for any types of accident especially from fire clash, and will give proper training to the employees before employed them on dangerous machines.

5. Extra or separate rooms for entertainment and a Canteen should be maintained for the employyees and their children. The occupier should employ adequate number of welfare officers as prescribed in law where at least five hundred or more than that employees are working.

6. Provisions for making appeal by the aggrieved parties have also been incorporated in this Act. So any aggrieved person, such as owner/ occupiers, managers, inspectors and workers may file an appeal (The Factories Act, 1965).

\subsection{Protection of workers' rights under the UN} Documents: We tried to discuss in brief about the United Nations Conventions along with the Convention of International Labour Organization which is a specialized agency of United Nations.

\subsubsection{Protection under the UDHR - Universal} Declaration of Human Right-1948 incorporates those articles which are declaring the basic needs as rights of human being irrespective of time, place and character. And as of human being the garment employyees are also eligible to those rights and get

UniversePG I www.universepg.com protection of those articles. Brief discussion of those article are given below-

Every human being of this world is equally eligible to enjoy all rights and freedoms inserted in this universal declaration. And this enjoyment will be without any kind of distinction on the basis of race, colour, sex, language, religion, political national or social origin, property, birth or other status ${ }^{46}$. According to Art-7 of UDHR, all human beings are equal before the law and are equally entitled without any discrimination to equal protection of law. So workers as a specified class of human being will get equal treatment by law. Art- 8 of UDHR deals about effective remedy that means if fundamental rights ensured by the UDHR are being violated, then the right to get remedy will arise and competent national courts or tribunal will deliver that remedy. Alongside this Art-10 states about the right to judicial remedy which is an extra safeguard to the way of remedy. UDHR has also stated about the right to join in peaceful assembly and forming an association. This Article states that every human being can join without any obstacle to a peaceful assembly and association but no one can compel that person to join in an association ${ }^{47}$. So in that sense workers have full rights to form a trade union. Social security has also been ensured through Article 22 of UDHR. According to the light of this article, everyone as a society member, is entitled to get social security and will realize it, by the way of national efforts and international co-operation.

Moreover, this Inter-national document has also mentioned about Right to work. Article 23 specially mentions about the rights of the working class among which one's own free choice of employment, safeguard for unemployment, just and favorable condition in work place, equal pay for equal work without any discrimination, just and favorable remuneration as worthy of human dignity and the right to form a trade union for protecting their rights are protected by this universal declaration ${ }^{48}$. Right to rest and leisure for the employees has been referred through Article -24 of UDHR. Art-25 of UDHR states about the standard of living. Under the glaze of this article every human have the rights to lead a standard life where adequate safety to be ensured for him and his family for wellbeing and health which means enough or reasonable 
collection of food, housing and clothing, alongside that necessary social services and medical care is also needed to ensure (United Nations Universal Declaration of Human Rights, 1948). However, education as of right has been stipulated in Article -26 of the UDHR and the saying is, education shall be free, at least in the primary and foundational stages, so workers' and peasants' children will not deprived from elementary primary education. After all, it has clearly been mentioned in this international document that nothing of this document may be interpreted to imply or to perform any act aimed for destroying any rights and freedom incorporated in it ${ }^{49}$.

3.4.2 Protection under the ICESCR - International Convention on Economic, Social and Cultural Rights (ICESCR) provides that present state parties will recognize everyone's right to social security, including social insurance ${ }^{50}$. So as a specified class of citizen workers are also entitled to the right to social security and insurance. Article 10(2) of this document stipulates about the special protection of mothers, where a certain or reasonable time before and after her childbirth has been allocated for her. And for such period mothers who are service holder or worker in any factories should get paid leave or even leave with proper social benefits and security. Nevertheless, Article 11 of ICESCR articulates that present state Parties of this covenant will recognize everyone's right to an adequate standard of living for himself and his family, which will also include enough food, housing, clothing, and gradual up gradation of living conditions. Nevertheless, the state parties of this covenant will take necessary steps to assure these rights (International Covenant on Economic, Social and Cultural Rights, 1966).

\section{CONCLUSION:}

We have tried to discuss the rights of those people who work in garment sectors and also the present trends of violation of the workers' rights in Bangladesh. We have also tried to analyze several national and international laws dealing with the protection of employees' rights. Most of these workers are illiterate or holding below educational qualifications. So they don't even know their rights properly, protection of laws is far away from them. It was founded that the garment workers are indiscriminately been deprived of their basic rights, as well as the socio-economic condition of the garments workers is not in a lofty stage. And we hope that, it will help everyone, especially readers and workers, to know about their rights and concerning provisions of related laws in support of their rights. But at the end, it is undoubtedly recognizable that garment industries are the main staying force of our exporting business. So for the betterment of our country and people, we must have to sustain this Industry. But we know that there are so many problems existed in this sector. So, if we want to sustain our RMG sector then it is high time to come forward, combined well intention of government, BGMEA, workers and apparel brands or retailer can save this fruitful Industry.

\section{ACKNOWLEDGEMENTS:}

It is my great pleasure to acknowledge the help and cooperation I received from my Co-researchers during and before I started writing the present work. Nonetheless, this Article could not have been completed without the support, encouragement, advice and guidance I received from various angles such as my colleagues, teachers and renowned authors at different stages of my writing. It is indeed my pleasure to record my indebtedness to all of them.

\section{CONFLICTS OF INTEREST:}

This writing work has solely been carried out by us. Nevertheless, it has not previously been submitted to any other man or institutions. So, there is no conflict of interest about the authorship and genuineness of this Article.

\section{REFERENCES:}

1) Abdul Halim, Md, "The Bangladesh Labour Act', CCB Foundation, Dhaka, 2011.

2) ILO Conventions on Equality of treatment (social security), 1962. https://www.ilo.org/dyn/normlex/en/f?p=N ORMLEXPUB:12201:0::NO::P12201_INS TRUMENT_ID:312263

3) International Covenant on Civil and Political Rights, 1966. 
4) International Covenant on Economic, Social and Cultural Rights, 1966.

https://www.ohchr.org/EN/ProfessionalInter est/Pages/CESCR.aspx

5) Paul, Nirmal Chandra, "The Bangladesh Labour Act, 2006 \& Other Related Laws', Shams Publication, First published, $1^{\text {st }}$ August, 2007. http://library.green.edu.bd/cgi-bin/koha/opa c-detail.pl?biblionumber $=122$

6) Rahman, Dr. Rafique, "Future of Garment Industry', Sixth edition, 2012.

7) Sultana T. (2020). Labor demand and export-oriented industrialization of Bangladesh, Asian J. Soc. Sci. Leg. Stud., 2(6), 115-121. https://doi.org/10.34104/ajssls.020.01150121
8) The Bangladesh Labour Act, 2006, published by the government, 2006. https://www.ilo.org/dyn/travail/docs/352/A $\% 20$ Handbook\%20on\%20the\%20Banglades h\%20Labour\%20Act\%202006.pdf

9) The Constitution of People's Republic of Bangladesh. http://bdlaws.minlaw.gov.bd/act-367.html

10) The Factories Act, 1965.

11) United Nations Universal Declaration of Human Rights, 1948. https://www.un.org/en/universal-declaration-human-rights/

\section{ENDNOTES}

${ }^{1}$ Nazila Fathi, "Bangladesh Garment Industry Rebounds", International Finance Corporation Insights

${ }^{2}$ Email from International Labor Rights Forum Representative, to Committee Staff, Nov. 19, 2019 Ibrahim Hossain Ovi, “Women's Participation in RMG Workforce Declines," Dhaka Tribune, Mar. 3, 2018

${ }^{3}$ Report of Committee on Foreign Relations, US Senate, "Seven Years After Rana Plaza, Significant Challenges Remain", Page-9, $116^{\text {th }}$ Congress, $2^{\text {nd }}$ Session, MARCH 5, 2020

${ }^{4}$ Julfikar Ali Manik and Jim Yardley, "Bangladesh finds gross negligence in factory fire”, New York Times, Dec.17, 2012

5 “'Bangladesh Factory Collapse Toll Passes 1,000,” BBC, May 10, 2013

${ }^{6}$ Report of Committee on Foreign Relations, US Senate, "Seven Years After Rana Plaza, Significant Challenges Remain", Chapter Four, Page-26, $116^{\text {th }}$ Congress, $2^{\text {nd }}$ Session, MARCH 5, 2020

${ }^{7}$ The Alliance concluded its operations in December 2018. “Alliance Announces End of Its Tenure," New Age Business, Dec. 14, 2018; The Accord is due to wrap up operations in 2020. "Bangladesh Factory Safety Monitors Get Court Extension," France24, May 19, 2019, Chapter Four.

${ }^{8}$ Report of Committee on Foreign Relations, US Senate, "Seven Years After Rana Plaza, Significant Challenges Remain", Executive Summary, Page-1-2, $116^{\text {th }}$ Congress, $2^{\text {nd }}$ Session, MARCH 5, 2020

${ }^{9}$ Section- 115,116 \& 117 of Bangladesh labour Act-2006

${ }^{10}$ The Financial Express, "Long Working hours a major challenge in RMG sector: Study”, 08 October-2018

${ }^{11}$ International Labour Organization, "Working hours and leave in the Bangladesh RMG industry", 08 January-2020

${ }^{12}$ Rob Wayss, Executive Director, Accord on Fire and Building Safety in Bangladesh, Interview with Committee Staff, Senate Committee on Foreign Relations Staff Visit to Dhaka, Bangladesh, July-2019

${ }^{13}$ Section- 123, Bangladesh labour Act-2006

${ }^{14}$ The Daily Star, 28 April-2015

${ }^{15}$ Human Rights Watch, Report on “'However raises their head suffers the most. Workers' rights in Bangladesh's garment factories",

${ }^{16} \mathrm{Ibid}$

${ }^{17}$ The Daily Prothom Alo, $9^{\text {th }}$ April-2019

${ }^{18}$ Deutsche Welle (Dw.com), $14^{\text {th }}$ January-2019

${ }^{19}$ Ibid 
${ }^{20}$ The Daily Prothom Alo, Analyzing report by Kapona Aktar on “'They didn't took responsibility of the workers", $05^{\text {th }}$ November, 2020

${ }^{21}$ Dhaka Tribune, 'Sick workers sudden death in Apparels factory Gazipur', 11 July, 2019

${ }^{22}$ The Daily Bangladesh Protidin, "Apparel workers death in Gazipur, road blocked", 25 October, 2020 Rising BD.com, 24 October, 2020

${ }^{23}$ David A Waugh, "The ILO and Human rights, comparative labour law”, 5(2): 186-196 (spring 1982)

${ }^{24}$ Siddiqi, H.G.A. 2004, 'The Ready-made garments Industry of Bangladesh', The University press limited, First Edition, P-192, 121, Dhaka, Bangladesh

${ }^{25}$ Section-2(45), The Bangladesh Labour Act, 2006

${ }^{26}$ Section-122, Ibid

${ }^{27}$ Section-123, Ibid

${ }^{28}$ Section-124, Ibid

${ }^{29}$ Section-100, Ibid

${ }^{30}$ Section-103, Ibid

${ }^{31}$ Section-34, Ibid

${ }^{32}$ Section-37, Ibid

${ }^{33}$ Section-39, Ibid

${ }^{34}$ Section-41, Ibid

${ }^{35}$ Section-45, Ibid

${ }^{36}$ Section-46, Ibid

${ }^{37}$ Section-48, Ibid

${ }^{38}$ Section-49, Ibid

${ }^{39}$ Article-19, The Constitution of People's Republic of Bangladesh

${ }^{40}$ Article-15, Ibid

${ }^{41}$ Article-20, Ibid

${ }^{42}$ Article-27, Ibid

${ }^{43}$ Article-34, Ibid

${ }^{44}$ Article-40, Ibid

${ }^{45}$ Chapter II, Factories Act-1965

${ }^{46}$ Article-2, Universal Declaration of Human Rights (UDHR), 1948

${ }^{47}$ Article-20, Ibid

${ }^{48}$ Article-23, Ibid

${ }^{49}$ Article-30, Ibid

${ }^{50}$ Article-09, International Convention on Economic, Social and Cultural Rights (ICESCR)

Citation: Al-Amin M, Alam S, and Hossain S. (2020). Analysis of the present condition of garment workers' rights and its protection under domestic and international legal framework: Bangladesh perspective, $B r . J$. Arts Humanit., 2(6), 101-112. https://doi.org/10.34104/bjah.02001010112 @ 